\title{
L. G. Alexander: a statue in Beijing
}

\section{A Chinese tribute to Louis Alexander}

[An obituary tribute to Louis Alexander appeared in ET72 (18:4), October 2002, under the title 'We looked, listened and learned'. In it, among other areas of interest, his vast impact on English teaching and learning in China is discussed. That impact is further confirmed in the report below and in the accompanying texts of four speeches given at the unveiling of the commemorative statue.]

IN BEIJING, on 4 November 2003, L. G. Alexander - for many years the world's foremost author of English language teaching materials - was formally commemorated. A bronze statue was raised in his honour in the grounds of the Foreign Language Teaching and Research Press (FLTRP), the publishing house of the Beijing Foreign Studies University and one of China's largest schoolbook publishers. The statue was jointly sponsored by FLTRP and Pearson Education Asia.

In the presence of five hundred guests, the President of FLTRP, Mr Li Pengyi, made an emotional opening speech, in which he recalled learning English from Louis Alexander's course New Concept English (Longman 1967). He could not have imagined then that one day he and Alexander would become friends, and that he would commission the vastly successful New Concept English (Chinese) New Edition (1997).

Mr Li's speech was followed by a tribute from Mr William T. Ethridge, President of Pearson Higher Education, International and Professional Divisions, who emphasized the worldwide success of Alexander's works, their significance in terms of international publishing, and their importance to Longman (Pearson). The third speaker was Party Secretary, Professor Yang Xueyi, on behalf of the Beijing Foreign Studies University, who affirmed the University's appreciation of his contribution to its work and to the learning of English throughout
China. Professor Yang was followed by Sir Christopher Hum, the British Ambassador to China, who noted that Louis Alexander was also the author of Follow $\mathrm{Me}$, an enduringly popular course that helped make studying English a national preoccupation. In the closing speech, Julia Alexander spoke about his concerns as an author.

She said that, in a career spanning four decades, her husband wrote out of a desire to provide 'the answer to the problem', each work representing his view on some aspect of language teaching and learning. Perhaps his most radical insight was that two syllabuses are needed side by side: a content syllabus (taught in terms of grammar and vocabulary) and a skills syllabus (what learners need the language for). She also gave her view of why Louis' learners became so attached to his works: 'New Concept English charms because it is serene. Like Louis himself, his characters are funny, fallible, kind, polite, innocent at heart. Louis' learners have always loved the author's voice. This voice is the true reflection of the man.'

Professor Yang and Sir Christopher Hum, representing the ties between China and Britain, jointly unveiled the statue, and, as the red cloth fell away, the audience bowed to the statue and applauded. The inscription on the base of the statue reads: 'Louis George Alexander, born 15 January 1932 - died 17 June 2002: The man who cracked the linguistic code of the English language and made it learnable for millions of students worldwide through New Concept English and many other coursebooks.' The texts of the four speeches follow.

\section{Li Pengyi, President of FLTRP}

Sir Christopher, Mr Will Ethridge, Mr T.C. Goh, Mrs Julia Alexander, Professor Yang Xueyi, Professor He Qixin, Ladies and Gentlemen, Good Afternoon: First of all, please allow me to 
express my warmest welcome to all the distinguished guests on behalf of the Foreign Language Teaching and Research Press. This is a significant occasion dedicated to the memory of Mr Louis Alexander, the author who has cracked the linguistic code of the English language and made it learnable for millions of students worldwide through many of his works. His New Concept English, with its revolutionary pedagogic rationale, has proved to be a legendary and continual success in China.

My personal connection with New Concept English started 25 years ago, when I first began to learn the language, at the age of 23 . We all know that learning a foreign language is a formidable challenge for adults. But New Concept English inspired my interest and built up my confidence. Even today I can still recite some passages I studied back then, though little did I expect that I would one day have the opportunity to work with the author himself.

In 1993, shortly after I took the responsibility as president of FLTRP, we made the proposal to Longman for co-publishing New Concept English in China. In 1995, FLTRP invited Mr Louis Alexander for an academic visit to China and proposed to Longman for a revised edition of New Concept English. We invited Professor He Qixin to be the co-author of the new edition. New Concept English New Edition was successfully brought out in 1997, thanks to the hard work of Mr Alexander and Professor He.

I was very fortunate to have the opportunity to accompany Mr Alexander for more than ten days during his visit to China in 1995. I listened to his lectures many times and had numerous discussions with him on the revision of New Concept English. This first contact initiated a friendship between us that was to deepen further as time went by. The better I got to know him, the greater respect I felt for Louis both as a man and as an author. I admire him for his strong sense of responsibility and impeccable professionalism. A scholar of profound learning and wisdom, he was yet so modest and tolerant. His sense of humour and respect for others made him an ideal friend one can ever dream of. We extended our range of cooperation as our friendship grew. When we met in London in April 2002, two months before he passed away, Louis was still thinking about English learners in China and making plans for our future cooperation. Our grief over his death has somewhat been alleviated by the fact that our friendship continues with Mrs Julia
Alexander, who is in her own right a talented teacher and writer, and who has been carrying on the work Louis has left unfinished.

Besides the authors' contribution, we cannot really talk about New Concept English without mentioning Pearson Longman, our long-term partner. As a matter of fact, New Concept English New Edition, specially tailored for Chinese students, could not have come into being without this partnership. Over the last few years, cooperation between our two organizations has developed even further, with the tremendous support and personal effort of Mr T.C. Goh, president of Pearson Education Asia. Cooperative projects with Pearson currently account for nearly 60 percent of FLTRP's international business. The joint inauguration of the statue of Mr Alexander and the present visit of Mr Will Ethridge, Mr T.C. Goh, Mr Golden Hong, and Mrs Julia Alexander to FLTRP have opened up a new era in the course of our cooperation. We have full confidence that PearsonFLTRP cooperation will continue to develop at a steady and faster pace.

At this occasion, I would like to express our sincere thanks to the British Embassy. For many years, FLTRP has maintained very good relationship of cooperation with the British Embassy and the British Council. The Embassy assisted the establishment of the China University English Speaking Association, with its head office at FLTRP. We also jointly publish Teaching English in China, a well-recognized academic journal among professionals. The British Embassy and British Council also offer generous support to the annual FLTRP Cup National English Debating Contest. Sir Christopher attended the grand final of this year's contest in April and personally presented awards to the winners. Such cooperation has greatly helped to promote English education in China.

In the face of an increasingly integrated global economy, China is developing ever closer ties with the rest of the world. English, as the most influential international language, is gradually turning from a special skill to a required qualification for more and more people in this country. Hundreds of thousands of Chinese students have drawn inspiration from New Concept English, the best-recognized classical English course book. And many more are bound to follow suit. We can already see the emerging of a New Concept English industry, inclusive of textbooks, supplementary materials, multi-media products, and training pro- 


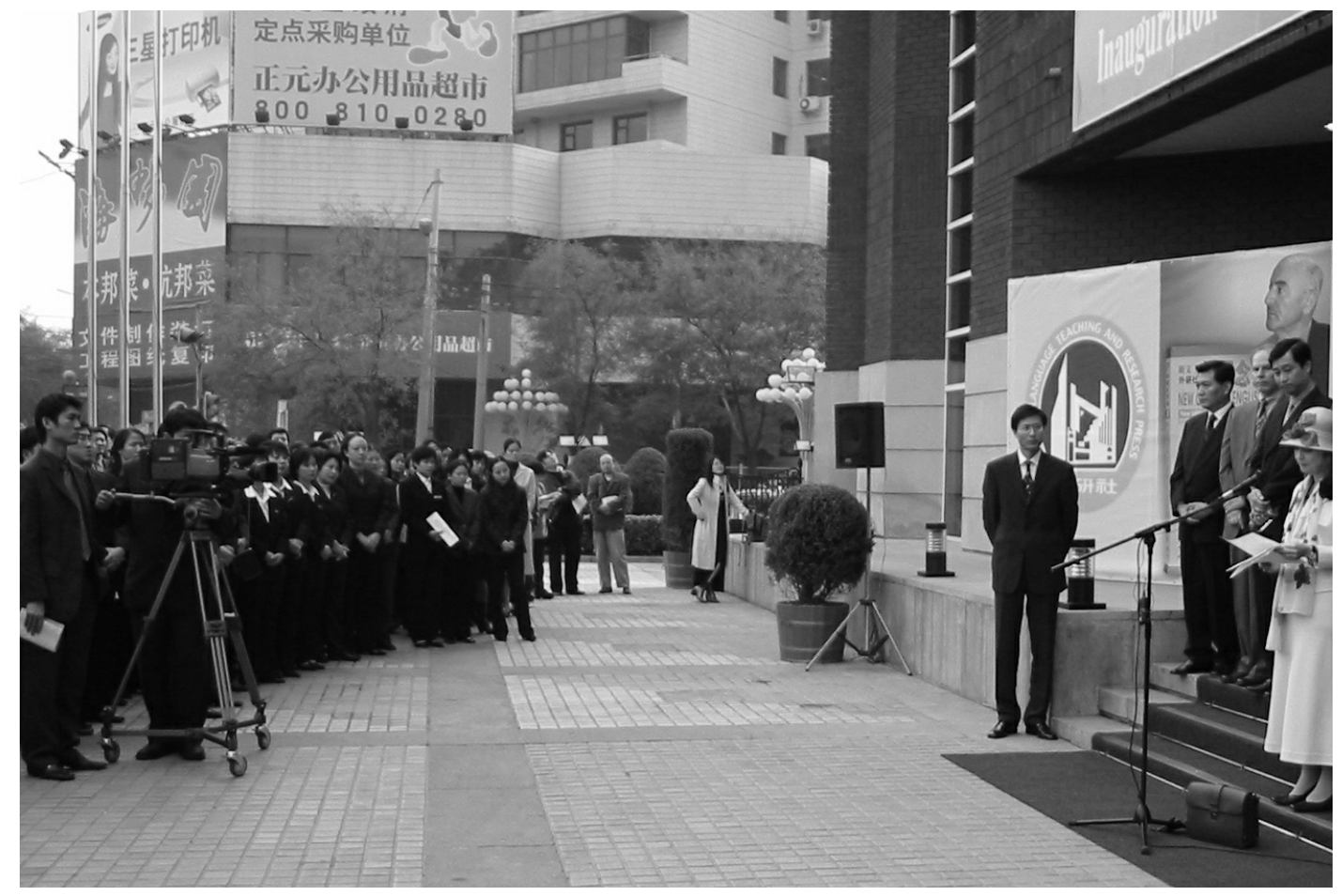

grammes. One indication of this possibility is the fact that we have sold seven million copies of NEC in the past six years.

Louis had actually predicted the growth of this new industry and all we need to do is to materialize his far-sighted vision. We have already had discussions with $\mathrm{Mr}$ Ethridge, $\mathrm{Mr}$ Goh, Mrs Alexander, and Professor He Qixin on the development of this new industry. Louis Alexander has left us a priceless legacy, New Concept English. It is now up to us to tap the many potentials of the work. This, I believe, is one of the best ways to commemorate the great author. Thank you!

\section{Will Ethridge, President of Pearson} Higher Education, International and Professional Divisions

Party Secretary of the University Professor Yang, Sir Christopher, Mr Li, Mrs Julia Alexander, ladies and gentlemen: It is my great honour to represent Pearson Education and its subsidiary, Longman Publishers, at this ceremony. Pearson Education is the world's largest educational publisher. While we have thousands of outstanding authors around the world, I want to point out that Mr Louis Alexander is arguably the most important author of Longman, so you can imagine how special this ceremony is to those of us present from Pearson Longman.

During the four decades of his career, Louis Alexander published many influential books including New Concept English, Follow Me, and The Longman English Grammar, to name just a few. In fact, he was named in the Guinness Book of Records as the author with the highest royalty income in the world. In China, Louis Alexander is known especially for his work, New Concept English. First published in 1967, this work not only swept the western world but also quickly became the most popular English course in China. In 1997 a new edition was published. This edition was written specifically to address the needs of English learners in China.

As the publisher of Louis Alexander, we have met so many people across China, from different walks of life and different age groups, who tell us how much they admire his work. Let me quote just one example of the many comments we have received over the years. I quote, 'Louis Alexander knew exactly what Chinese learners need at different stages of learning English. He was well aware of the enjoyment as well as the frustrations of learning English. It would be very hard to find an English learner in China who hasn't used Louis Alexander's books.'

The great success of the new edition of New 
Concept English would never have been possible without the outstanding work of the coauthor, Professor He, and the commitment of FLTRP. The high quality of Louis Alexander's and Professor He's authorship was matched by the publishing excellence of Longman and FLTRP, and New Concept English fully established Louis Alexander as the indisputable ELT guru in China. For Longman, the new edition of New Concept English is a record breaker. Since its publication, the sales of the four main books alone, not to mention the support components, have exceeded 7 million copies. Book One was reprinted for the 50th time this summer.

I offer my admiration and gratitude to $\mathrm{Mr} \mathrm{Li}$ and the talented employees of FLTRP. Not only did they do a great job of launching the new edition, but also sales continue to increase six years after publication - a testament to their continuing efforts and commitment to the series. I truly believe that the future of New Concept English is bright in the capable hands of $\mathrm{Mr} \mathrm{Li}$ and his team. I also believe that Longman's collaboration with FLTRP will be a long and happy one.

As a representative of Pearson Education, I would like also to reiterate Pearson's commitment to publishing world-class ELT material for China. We are sincere and serious about sharing our best intellectual properties with China because we believe China is a great country with a most promising future. We want to contribute as much as we can to China's goal of establishing English as the second language of the country.

In closing, I'd like to express my very special thanks to Mrs Julia Alexander. She is a former English teacher and has spent many years as a teacher-training consultant. Longman has had a long association with Julia, and it was when she was working for Longman that, in fact, she first met Louis. We are inspired by her unrelenting commitment to quality, we are guided by her in-depth understanding of the needs of English learners, and we are blessed by her intelligence and charm. The spirit of Louis shines through her. I am certain that New Concept English will continue to flourish with Julia's help.

\section{Yang Xueying, party secretary of the Beijing Foreign Study University}

Sir Christopher Hum, Mr Will Ethridge, Mrs Julia Alexander, Ladies and Gentlemen, Good
Afternoon: On behalf of the Beijing Foreign Studies University, I'd like to express our warmest welcome to all our honorable guests who have come a long way to attend today's ceremony.

Mr Louis Alexander was a great English educator and author. He has won deep respect and love of millions of English students in China for his profound learning, rigorous scholarship, and fine personality. For many years, his New Concept English, Follow Me, Longman English Grammar, and many other works have been first choices as coursebooks and reference books for Chinese students. New Concept English and Follow $\mathrm{Me}$, in particular, have enabled millions of learners to enter the world of English.

New Concept English is the most successful cooperative project between the Foreign Language Teaching and Research Press and Pearson Education. Over the years the two organizations have maintained very close cooperation, which has led to a win-win situation for both the readers and the publishers. With the availability of high-quality books like New Concept English, students of English in China have had a better chance of learning the language well. On the part of the publishers, both FLTRP and Pearson Education have gained a share of the vast Chinese market of English books through their concerted efforts. The Beijing Foreign Studies University will continue to support the cooperation between the two publishers.

The joint inauguration of the statue of $\mathrm{Mr}$ Louis Alexander is yet another token of cooperation between FLTRP and Pearson Education, as well as the friendship between the author and his publishers. It is also the best way to commemorate this great author, whose works stand as living testimony of his tremendous contribution to China's English education.

This is also an excellent occasion for me to express our special thanks to the British Embassy and the British Council for their continuous support of the work of the Beijing Foreign Studies University and the university press, FLTRP. Over the years, the British Ambassador and officials of the British Council have offered generous assistance to many activities organized by our press, such as the national English debating and speaking contests. We hope to deepen such cooperation between the two sides in the future promotion of English education in China.

Finally, I'd like to say a special Thank you to 


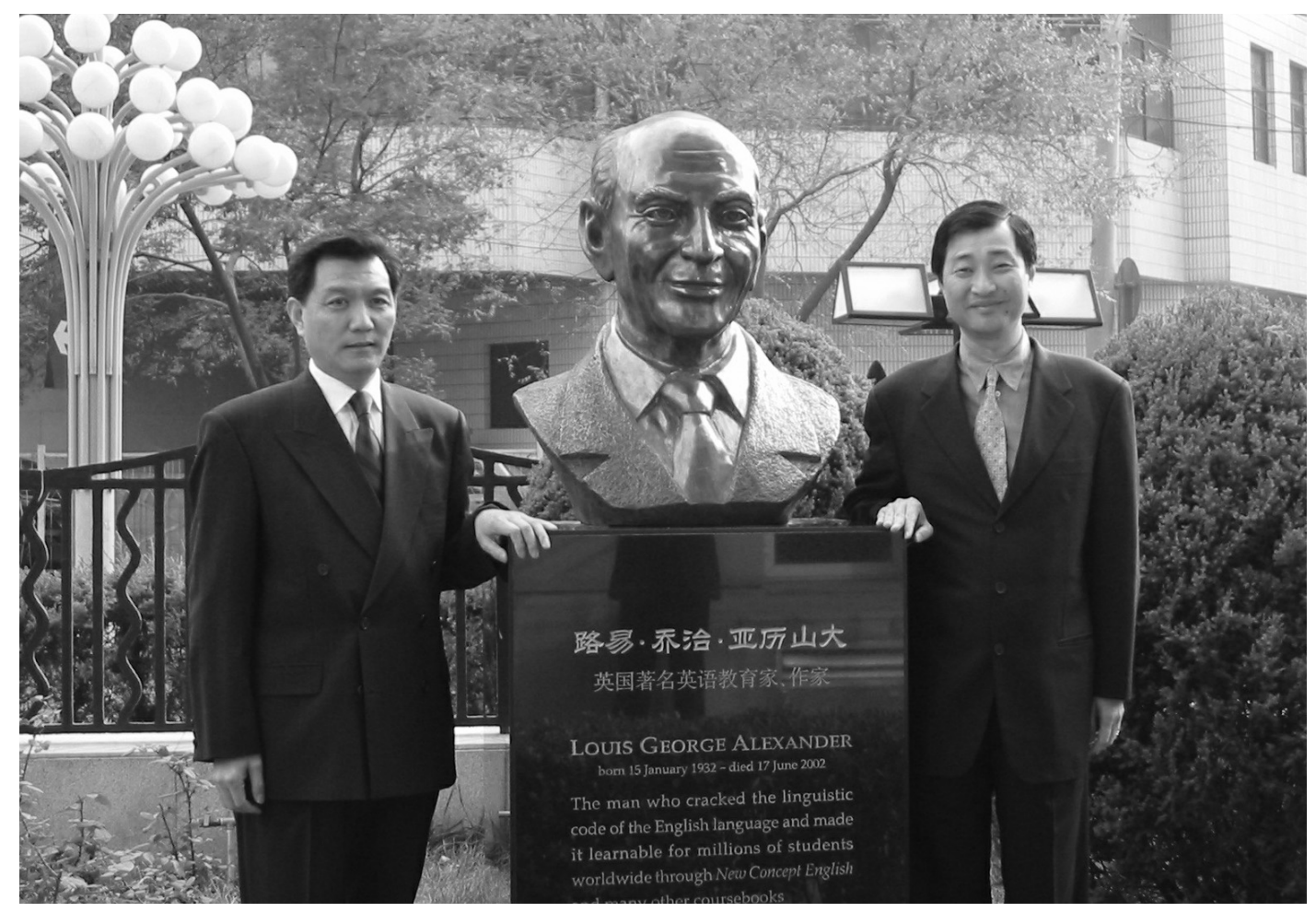

Mrs Julia Alexander for being here to share with us your memory of Mr Louis Alexander. Thank you all!

\section{Julia Alexander}

Party Secretary Professor Yang, Sir Christopher, Mr Li Pengyi, distinguished guests, colleagues and friends, ladies and gentlemen:

It is my great honour to be here today to represent my husband, Louis Alexander. I wish he could have been with us today in person though I have to say that he is probably not very far away from us now. He would have enjoyed the occasion, and would have embraced the honour and affection that it represents. He would have wished me to express, on his behalf, his delight in the bond between China - and some very special friends in China - and him.

Louis' first book, Sixty Steps to Précis, was published, near to his 30th birthday, in 1962. He wrote it because it seemed to him to be the answer to the problem. He was seeing classes of young people who had studied English daily for seven years, and who still could not write a meaningful sentence. He applied his intellect to the problem, and wrote a book. This was the pattern of his life. Sixty Steps to Précis contained the seed from which a mighty tree would grow.

This was the process that drove all his work. He would analyze what the learning task required, then, by a formidable exercise of intellect, he would organize the task into a progressive series of manageable tasks. The student simply needed to complete each assignment and work steadily towards success.

Louis was also concerned with motivation. Did the learners like English speakers enough to want to learn their language? In New Concept English, he presented his answer. People are motivated by what makes them happy. Everyone enjoys a story. A good story engages our curiosity, our surprise, our feelings. It engages us through our shared humanity. Louis was a man of immense charm. He had a great sense of fun and a deep spring of personal happiness. New Concept English charms because it is serene. Like Louis himself, his characters are funny, fallible, kind, polite, innocent at heart - never unkind, immoral or rude. Louis' learners have always loved the author's voice. This voice is the true reflection of the man.

In New Concept English, Louis developed his 
idea that there needed to be two syllabuses working together: there was the content syllabus - what was to be taught in terms of grammar and vocabulary - and the skills syllabus what the learners needed to do with the language. This definition of a skills syllabus led to Louis' creating the modern course-book. The book is not just a source of information. It is a pedagogic tool. The principles that he established, of intelligible page layouts, that a lesson in the book should match a lesson in class, that every lesson be a process of synthesizing content and skills - these principles were truly a 'new concept'. It was a pedagogic revolution that has informed textbooks in every discipline - not just in English Language Teaching.

New Concept English was published in 1967, and it swept the globe. It became the basis for training a generation of English Language teachers, from Chile to Uzbekistan. In China and elsewhere, New Concept English became the key to the door that opens on the English Language. In the last 30 years, millions of Chinese learners have studied New Concept English. Meanwhile, Louis continued to explore different ways of organizing the learning task. His work on syllabus in the 1970s led to the immensely influential Threshold Level, and to Follow Me for The Council of Europe. Then in the 1980s, he turned to writing reference books. The Longman English Grammar is the first rigorous description of English as a Foreign Language. He wrote it in answer to the question, Can you recommend $a$ good English Grammar?

Every day of his life, Louis sat down and wrote at white heat. One of his guiding principles as a man and an author was that he would never write the same book twice. Each new publication was his considered view on some aspect of language teaching and learning. He was always seeking 'the answer to the problem'. Throughout this time, he was also travelling world-wide, teaching, researching, lecturing - and making friends. And this brings us to China.

We had first come to China for a month in March 1981. In that month, we made many friends. Over the next 15 years, this connection developed steadily as a stable triangle: China, Louis and Longman. Now part of Pearson Education, Longman was the foremost educational publisher of the day, and as such had partnerships with a number of academic publishers

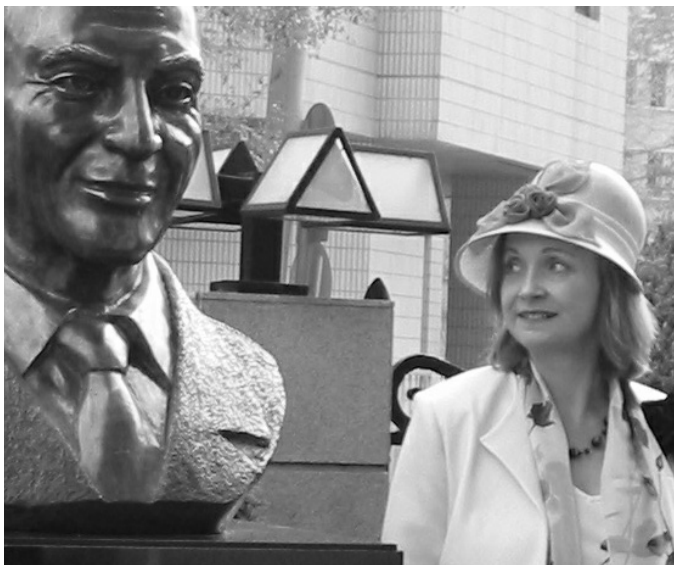

Julia Alexander

throughout China - as indeed Pearson Education does today. Of these, the most important were World Publishing of Shanghai, who first made New Concept English available in China, and The People's Education Press, publishers of Junior English for China, by Neville Grant and Louis for UNESCO. In the early 90s, we began discussions with Mr Li Pengyi of the Foreign Language Teaching and Research Press. Mr Li wanted to publish a new edition of New Concept English. While this work was going forward in collaboration with Professor He Qixin, FLTRP published many of Louis' other works, and the relationship flourished. Louis had a great gift for friendship. He was a loyal and affectionate friend. In $\mathrm{Mr} \mathrm{Li}$, he met another such man. Their meetings in China and in London created a strong bond of mutual respect and confidence. They trusted each other to get things right. When New Concept English New Edition was published in 1997, Louis was delighted.

At the end of 1997, Louis discovered that he had leukemia. In spite of his illness, he went on working when he could, and the friendship he felt for our colleagues at FLTRP was a great source of satisfaction to him. It has been a great comfort to his family to know that he was so well understood, so well loved and so sincerely mourned here in Beijing.

I wish to thank Mr Li Pengyi and the Foreign Language Teaching and Research Press on behalf of us all. I also thank Mr Will Etheridge of Pearson Education USA, and Mr T.C. Goh of Pearson Education Asia for participating in this commemoration of a great author and a great man. 